\title{
Highlight report the food additive dammar resin is a rat hepatocarcinogen
}

\author{
Tarek Ellethy ${ }^{1,2} \cdot$ Mohamed Alsenbesy $^{3} \cdot$ Mohamed M. M. Hashem $^{4}$
}

Received: 19 November 2018 / Accepted: 20 November 2018 / Published online: 23 November 2018

๑) Springer-Verlag GmbH Germany, part of Springer Nature 2018

Recently, Gi and colleagues from Osaka University in Japan published a 52-week chronic toxicity study and a 104-week carcinogenicity study of dammar resin in F344 rats (Gi et al. 2018). The authors demonstrated that hepatocellular adenomas and carcinomas were induced at $2 \%$ dietary concentrations of dammar resin, corresponding to $242 \mathrm{mg} / \mathrm{kg}$ b.w.l day, while $0.5 \%$ (178 $\mathrm{mg} / \mathrm{kg}$ b.w./day) was the no-observedadverse-effect level (NOAEL).

The results of $\mathrm{Gi}$ and colleagues are of high relevance, since dammar resin is used as a food additive and flavoring substance in drinks, frozen desserts and in chewing gum (Gi et al. 2018; Cohen et al. 2017, USP 2012). It is produced as an exudate from trees of Agathis, Hopea or Shorea genera (Gi et al. 2018). For risk evaluation, it should be considered that the concentrations of dammar resin in food are orders of magnitude lower than the doses used in the present study (Gi et al. 2018). Moreover, dammar resin was negative in genotoxicity and mutagenicity tests, including chromosomal aberration tests and the mouse bone marrow micronucleus assay (Hayashi et al. 2000), suggesting that the compound acts as a non-genotoxic rat liver carcinogen. Therefore, studies are required to analyze whether dammar resin acts similarly in rat and human hepatocytes or there

Tarek Ellethy

T.Ellethy@klinikum-stuttgart.de

Mohamed Alsenbesy

alsenbesy@web.de

Mohamed M. M. Hashem

hashemm41@yahoo.com

1 Radiotherapy Department, South Egypt Cancer Institute, Assiut University, Assiut, Egypt

2 Radiotherapy Department, Klinikum Stuttgart Katharinenhospital, Stuttgart, Germany

3 Department of Internal Medicine, Faculty of Medicine, South Valley University, Qena, Egypt

4 Pharmacology Department, Faculty of Veterinary Medicine, Cairo University, Cairo, Egypt are major differences. In vitro cultures of primary hepatocytes represent a well-established tool for interspecies comparison (Vatakuti et al. 2017; Gu et al. 2018; Rodrigues et al. 2018; Arbo et al. 2016; Ghallab et al. 2016; Ghallab 2017a, b; Hammad 2013; Hammad et al. 2015). Readout comprises not only the cytotoxicity but also gene expression and hepatocellular functions (Deharde et al. 2016; Godoy et al. 2016, 2018; Jansen et al. 2017; Reif et al. 2015; Grinberg et al. 2014; Stöber 2016; Hammad et al. 2017, 2018). This is of interest, since dammar resin induces at least seven cytochrome $\mathrm{P} 450$ isoforms rodents in vivo and also generates reactive oxygen species in rat liver (Gi et al. 2018), key events known to be associated with non-genotoxic hepatocarcinogenesis (Cohen 2010; Hall et al. 2012; Leist et al. 2017; Godoy et al. 2013; Hewitt et al. 2007; Nwosu et al. 2017). Therefore, a comparison of these and similar endpoints, e.g. nuclear receptor activation, in rat and human hepatocytes will be an important step to improve the risk assessment of dammar resin as a food additive.

\section{Compliance with ethical standards}

Conflict of interest The authors declare that they have no conflict of interest.

\section{References}

Arbo MD, Melega S, Stöber R, Bastos M, Carmo H, Hengstler JG (2016) Hepatotoxicity of piperazine designer drugs: up-regulation of key enzymes of cholesterol and lipid biosynthesis. Arch Toxicol 90(12):3045-3060

Cohen SM (2010) Evaluation of possible carcinogenic risk to humans based on liver tumors in rodent assays: the two-year bioassay is no longer necessary. Toxicol Pathol 38(3):487-501. https://doi. org/10.1177/0192623310363813

Cohen SM, Fukushima S, Guengerich FP, Hecht SS, Rietjens IMCM, Smith RL (2017) GRAS flavoring substances 28. https://www. femaflavor.org/publications/gras-publications/gras-28 
Deharde D, Schneider C, Hiller T, Pratschke J, Zeilinger K, Damm $\mathrm{G}$ (2016) Bile canaliculi formation and biliary transport in 3D sandwich-cultured hepatocytes in dependence of the extracellular matrix composition. Arch Toxicol 90(10):2497-2511. https://doi. org/10.1007/s00204-016-1758-z

Ghallab A (2017a) Highlight report: Metabolomics in hepatotoxicity testing. EXCLI J 16:1323-1325. https://doi.org/10.17179/excli 2017-1041

Ghallab A (2017b) Highlight report: Monitoring cytochrome P450 activities in living hepatocytes. EXCLI J 16:1330-1331

Ghallab A, Cellière G, Henkel SG, Drasdo D, Gebhardt R, Hengstler JG (2016) Model-guided identification of a therapeutic strategy to reduce hyperammonemia in liver diseases. J Hepatol 64(4):860-871

Gi M, Fujioka M, Yamano S, Kitano M, Hayashi SM, Wanibuchi H (2018) Chronic dietary toxicity and carcinogenicity studies of dammar resin in F344 rats. Arch Toxicol. https://doi.org/10.1007/ s00204-018-2316-7

Godoy P, Hewitt NJ, Albrecht U, Xu JJ, Yarborough KM, Hengstler JG (2013) Recent advances in 2D and 3D in vitro systems using primary hepatocytes, alternative hepatocyte sources and nonparenchymal liver cells and their use in investigating mechanisms of hepatotoxicity, cell signaling and ADME. Arch Toxicol 87(8):1315-1530. https://doi.org/10.1007/s00204-013-1078-5

Godoy P, Widera A, Schmidt-Heck W et al (2016) Gene network activity in cultivated primary hepatocytes is highly similar to diseased mammalian liver tissue. Arch Toxicol 90(10):2513-2529. https:// doi.org/10.1007/s00204-016-1761-4

Godoy P, Schmidt-Heck W, Hellwig B, ...Walter J, Blüthgen N, Hengstler JG (2018) Assessment of stem cell differentiation based on genome-wide expression profiles. Philos Trans R Soc Lond B Biol Sci 373(1750):20170221. https://doi.org/10.1098/rstb.2017.0221

Grinberg M, Stöber RM, Edlund K, Leist M, Rahnenführer J, Hengstler JG (2014) Toxicogenomics directory of chemically exposed human hepatocytes. Arch Toxicol 88(12):2261-2287. https://doi. org/10.1007/s00204-014-1400-x

Gu X, Albrecht W, Edlund K, Han B, Hengstler JG, Stoeber R (2018) Relevance of the incubation period in cytotoxicity testing with primary human hepatocytes. Arch Toxicol. https://doi.org/10.1007/ s00204-018-2302-0

Hall AP, Elcombe CR, Foster JR, Schulte A, Strauss V, York MJ (2012) Liver hypertrophy: a review of adaptive (adverse and non-adverse) changes-conclusions from the 3rd international ESTP expert workshop. Toxicol Pathol 40(7):971-994

Hammad S (2013) Advances in 2D and 3D in vitro systems for hepatotoxicity testing. EXCLI J 12:993-996

Hammad S, Abdel-Wareth AAA, El-Sayed Y (2015) In vitro-in vivo correlation: Hepatotoxicity testings. JEAAS 1(3):384-387
Hammad S, Braeuning A, Meyer C, Mohamed FEZA, Hengstler JG, Dooley S (2017) A frequent misinterpretation in current research on liver fibrosis: the vessel in the center of $\mathrm{CCl} 4$-induced pseudolobules is a portal vein. Arch Toxicol 91(11):3689-3692. https ://doi.org/10.1007/s00204-017-2040-8

Hammad S, Othman A, Meyer C, Amasheh S, Hengstler JG, Dooley S (2018) Confounding influence of tamoxifen in mouse models of Cre recombinase-induced gene activity or modulation. Arch Toxicol 92(8):2549-2561. https://doi.org/10.1007/s00204-018-2254-4

Hayashi M, Matsui M, Ishii K, Kawasaki M (2000) Environ Mutagen Res 22:27-44. http://ci.nii.ac.jp/naid/110001710452/en (in Japanese). Accessed 10 Nov 2018

Hewitt NJ, Lechón MJ, Houston JB, LeCluyse E, Groothuis GM, Hengstler JG (2007) Primary hepatocytes: current understanding of the regulation of metabolic enzymes and transporter proteins, and pharmaceutical practice for the use of hepatocytes in metabolism, enzyme induction, transporter, clearance, and hepatotoxicity studies. Drug Metab Rev 39(1):159-234

Jansen PL, Ghallab A, Vartak N, Reif R, Schaap FG, Hampe J, Hengstler JG (2017) The ascending pathophysiology of cholestatic liver disease. Hepatology 65(2):722-738

Leist M, Ghallab A, Graepel R, Kroese D, van de Water B, Hengstler JG (2017) Adverse outcome pathways: opportunities, limitations and open questions. Arch Toxicol 91(11):3477-3505. https://doi. org/10.1007/s00204-017-2045-3

Nwosu ZC, Megger DA, Hammad S, Sitek B, Roessler S, Ebert MP, Meyer C, Dooley S (2017) Identification of the consistently altered metabolic targets in human hepatocellular carcinoma. Cell Mol Gastroenterol Hepatol 4(2):303-323. https://doi.org/10.1016/j. jcmgh.2017.05.004

Reif R, Karlsson J, Günther G, Kaye PM, Hengstler JG, Jirstrand M (2015) Bile canalicular dynamics in hepatocyte sandwich cultures. Arch Toxicol 89(10):1861-1870. https://doi.org/10.1007/s0020 4-015-1575-9

Rodrigues RM, Kollipara L, Chaudhari U, Vanhaecke T, Rogiers V, Vinken M (2018) Omics-based responses induced by bosentan in human hepatoma HepaRG cell cultures. Arch Toxicol 92(6):1939_ 1952. https://doi.org/10.1007/s00204-018-2214-z

Stöber R (2016) Pathophysiology of cholestatic liver disease and its relevance for in vitro tests of hepatotoxicity. EXCLI J 15:870-871. https://doi.org/10.17179/excli2016-864

USP (2012) Food chemicals codex, 8th edn. The United States Pharmacopeial Convention, Washington, DC

Vatakuti S, Olinga P, Pennings JLA, Groothuis GMM (2017) Validation of precision-cut liver slices to study drug-induced cholestasis: a transcriptomics approach. Arch Toxicol 91(3):1401-1412. https ://doi.org/10.1007/s00204-016-1778-8 